JoANNA DOMINIAK

Uniwersytet im. A. Mickiewicza, Poznań, Polska

\title{
Zmiany zróżnicowania przestrzennego poziomu rozwoju spoleczno-gospodarczego w Polsce w latach 2000-2010 w aspekcie innowacyjnej gospodarki i otoczenia biznesu
}

\author{
Changes in the spatial differentiation of the level of socio- \\ -economic development in Poland in the years 2000-2010 \\ in terms of innovative economy and business environment
}

Streszczenie: Innowacyjna gospodarka i otoczenie biznesu stanowią ważne czynniki rozwoju społeczno-gospodarczego regionów. W niniejszym opracowaniu analiza zróżnicowania przestrzennego poziomu rozwoju społeczno-gospodarczego w Polsce w latach 2000-2010 w aspekcie innowacyjnej gospodarki i otoczenia biznesu przeprowadzona została na podstawie 13 cech odnoszących się do jednostek przestrzennych poziomu regionalnego (NUTS2) oraz 3 cech odnoszących się do poziomu lokalnego (NUTS4). Otrzymane rozkłady przestrzenne obszarów wzrostu i stagnacji gospodarczej dla 11 obserwacji w okresie $2000-2010$ pozwoliły na wskazanie istotnych prawidłowości rozwoju tych obszarów i identyfikacji czynników wpływających na te rozkłady.

Szczegółowe cele tej analizy są następujące:

1. Identyfikacja rozkładu przestrzennego poziomu rozwoju w aspekcie: innowacyjna gospodarka i otoczenie biznesu w Polsce, prowadząca do wyróżnienia obszarów wzrostu i obszarów stagnacji.

2. Analiza trajektorii rozwoju obszarów wzrostu i obszarów stagnacji w badanym aspekcie, w tym także próba odpowiedzi na wpływ kryzysu gospodarczego na tę sferę gospodarki.

3. Identyfikacja czynników wplywających na rozmieszczenie i zmienność obszarów wzrostu i obszarów stagnacji w aspekcie: innowacyjna gospodarka i otoczenie biznesu.

Artykuł prezentuje wyniki projektu badawczego: „Rozwój społeczno-gospodarczy a ksztaltowanie się obszarów wzrostu i stagnacji gospodarczej", finansowanego przez Narodowe Centrum Nauki (N N306 791940, realizowanego w Zakładzie Analizy Regionalnej Uniwersytetu im. A. Mickiewicza w Poznaniu.

\footnotetext{
Abstract: The innovative economy and business environment are important factors in socio-economic development of regions. In this paper, the analysis of the spatial differentiation of the socio-economic development level in Poland in the years 2000-2010 in the aspect of the innovative economy and the business environment has been carried out based on 13 characteristics related to the spatial units at the regional level (NUTS 2) and 3 characteristics relating to the local level (NUTS4). The resulting spatial
} 
distributions of economic growth and stagnation areas for 11 observations in the period from the year 2000 to 2010 made it possible to identify the essential features of the development of these areas, and to identify factors influencing these distributions.

The specific objectives of this analysis are as follows:

1. Identification of the spatial distribution of the development level in terms of: innovative economy and the business environment in Poland, leading to distinctions of the areas of growth and stagnation.

2. Analysis of the trajectory of the development of growth and stagnation areas in this aspect, including an attempt to answer to the degree to which the economic crisis has an impact on this part of economy. 3. Identification of factors affecting the distribution and variability of growth and stagnation areas in terms of: innovative economy and the business environment.

This article presents the results of the research project "Socio-economic development and the development of the areas of growth and economic stagnation", funded by the National Science Centre (N N306 791940), conducted at the Department of Regional Studies University. Adam Mickiewicz University in Poznan.

Slowa kluczowe: innowacyjna gospodarka; otoczenie biznesu; Polska; rozwój regionalny

Keywords: business environment; innovative economy; Poland; regional development

\section{WsTĘP}

Innowacyjna gospodarka i otoczenie biznesu stanowią ważne czynniki rozwoju spoleczno-gospodarczego regionów (Churski, Dominiak, 2013). Zdolność generowania i przyswajania szeroko pojętych innowacji (zarówno technologicznych, jak i organizacyjnych) to ważny element determinujący rozwój regionów (por. Chmielewski i in., 2001). Jest to szczególnie istotny problem w dobie rozwoju gospodarki opartej na wiedzy. To wlaśnie innowacyjność gospodarki określa w coraz większym stopniu przewagę konkurencyjną państw i regionów. Jednym z czynników rozwoju innowacyjnej gospodarki jest właściwie uksztaltowane środowisko działalności gospodarczej, które określa się jako otoczenie biznesu. W szerokim znaczeniu otoczenie biznesu obejmuje wyposażenie instytucjonalne oraz środowisko innowacyjne (por. Dominiak, 2004, 2006, 2013). Otoczenie biznesu odgrywa istotną rolę w generowaniu i rozpowszechnianiu innowacji. Ukształtowane otoczenie biznesu z jednej strony jest czynnikiem lokalizacji działalności gospodarczej, a z drugiej warunkuje dynamiczny rozwój społeczno-gospodarczy. Znaczenie tych instytucji wzrasta w procesie rozwoju opartego na postfordowskim modelu organizacji produkcji (por. Stryjakiewicz, 1999; Chojnicki, 1993, 1999). Według Hausnera i in. (1997) instytucje otoczenia biznesu stymulują lokalną przedsiębiorczość, inicjują działalność innowacyjną i umożliwiają transfery nowoczesnych technologii. Poprzez relację: innowacja-przemysł przyczyniają się do rozwoju nowoczesnego przemysłu i wzrostu innowacyjności gospodarki (por. Aydalot i Keeble, 1988; Chmielewski i in., 2001; Doloreux, 2002; Lehner i in., 2006; Markiewicz, 2007; Matusiak, 2007; Todtling $\mathrm{i}$ in., 2008; Wysocki, 2009).

Innowacyjność oraz otoczenie biznesu przyczyniają się w istotny sposób do rozwoju i wzrostu konkurencyjności regionów, który z kolei powoduje dalszy rozwój instytucji otoczenia biznesu (w odpowiedzi na zwiększony popyt na uslugi okołobiznesowe) 
i pobudza innowacyjność gospodarki (bogatszy region częściej inwestuje w nowe technologie). Innowacyjność gospodarek, podobnie jak stopień wyposażenia w instytucje otoczenia biznesu. wykazuje znaczne zróżnicowanie regionalne

W niniejszym opracowaniu analiza zróżnicowania przestrzennego poziomu rozwoju społeczno-gospodarczego w Polsce w latach 2000-2010 w aspekcie innowacyjnej gospodarki i otoczenia biznesu przeprowadzona została na podstawie 13 cech odnoszących się do jednostek przestrzennych poziomu regionalnego (NUTS2) oraz 3 cech odnoszących się do poziomu lokalnego (NUTS4). Otrzymane rozkłady przestrzenne obszarów wzrostu i stagnacji gospodarczej dla 11 obserwacji w okresie 2000-2010 pozwoliły na wskazanie istotnych prawidłowości w rozwoju tych obszarów i identyfikacji czynników wpływających na te rozklady.

Szczegółowe cele tej analizy są następujące:

1. Identyfikacja rozkładu przestrzennego poziomu rozwoju w aspekcie: innowacyjna gospodarka i otoczenie biznesu w Polsce. prowadząca do wyróżnienia obszarów wzrostu i obszarów stagnacji;

2. Analiza trajektorii rozwoju obszarów wzrostu i obszarów stagnacji w badanym aspekcie, w tym także próba odpowiedzi na wplyw kryzysu gospodarczego na tę sferę gospodarki;

3. Identyfikacja czynników wpływających na rozmieszczenie i zmienność obszarów wzrostu i obszarów stagnacji w aspekcie: innowacyjna gospodarka i otoczenie biznesu.

Artykuł prezentuje wyniki projektu badawczego: „Rozwój społeczno-gospodarczy a kształtowanie się obszarów wzrostu i stagnacji gospodarczej", finansowanego przez Narodowe Centrum Nauki (N N306 791940), realizowanego w Zakładzie Analizy Regionalnej Uniwersytetu im. A. Mickiewicza w Poznaniu.

W postępowaniu badawczym wykorzystano metodę wskaźnika syntetycznego Juliana Perkala oraz metodę analizy skupień k-średnich. Pierwszą metodę wykorzystano do uporządkowania analizowanych jednostek przestrzennych na skali poziomu rozwoju innowacyjnej gospodarki i otoczenia biznesu mierzonego wskaźnikiem syntetycznym. uwzględniającym wartości wskaźników oryginalnych opisujących wybrane do analizy cechy. Zastosowano syntetyczny wskaźnik Perkala ${ }^{1}$.

Drugą metodę wykorzystano do klasyfikacji uporządkowanych jednostek przestrzennych poprzez wy różnienie trzech grup: jednostek o najniższym poziomie rozwoju - obszary stagnacji, jednostek o przeciętnym poziomie rozwoju oraz jednostek o najwyższym poziomie rozwoju - obszary wzrostu. Analiza czynników rozwoju w aspekcie innowacyjnej gospodarki i otoczenia biznesu wykorzystuje również analizę regresji wielokrotnej. Wykorzystane dane statystyczne pochodzą z Banku Danych Lokalnych oraz z niepublikowanych materialów Głównego Urzędu Statystycznego.

Rozkład przestrzenny obszarów wzrostu i stagnacji gospodarczej na poziomie regionalnym (NUTS2) w aspekcie innowacyjnej gospodarki i otoczenia biznesu cechowal się w badanych okresach relatywnie dużą stabilnością (ryc. 1). Obszarami wzrostu zidentyfikowanymi na podstawie analizy skupień w ukladzie NUTS2 w każdym analizowanym roku

${ }^{1}$ Wskaźnik Perkala do oceny potencjału innowacyjnego województw wykorzystali m.in. Nowakowska A., Feltynowski M. (2009). Metoda oceny potencjału innowacyjnego regionów. W: A. Nowakowska (red.). Zdolności ınnowacyjne polskich regıonów, Lódź: Wydawnictwo Uniwersytetu Lódzkiego, s.11-24. 
były trzy województwa: mazowieckie. pomorskie i dolnośląskie. Województwo mazowieckie zdecydowanie dominowało pod względem każdej analizowanej cechy. Jego przewaga w szczególności uwidaczniala się w odniesieniu do liczby jednostek badawczo-rozwojowych, wielkości zatrudnienia i nakładów finansowych w tej sferze działalności. Wszystkie trzy analizowane województwa cechowały się także najwyższym poziomem rozwoju sektorów wysokiej techniki (usług o wysokim nasyceniu wiedzą i przemysłu wysokiej techniki) oraz usług dla biznesu (w odniesieniu do udziału pracujących i liczby podmiotów gospodarczych tego typu). W 2006 roku do grupy obszarów wzrostu dołączyło także województwo małopolskie, które powtórzyło swoją przynależność do regionów wzrostu także w latach 2007 i 2009.

Tab.1. Wykaz cech przyjętych do analizy w aspekcie: innowacyjna gospodarka i otoczenie biznesu²

\begin{tabular}{|c|c|}
\hline & $\begin{array}{l}\text { INNOWACYJNA GOSPODARKA I OTOCZENIE BIZNESU } \\
\text { - poziom regionalny (NUTS2) - } 13 \text { cech charakteryzujących } \\
\text { INNOWACYJNA GOSPODARKE I OTOCZENIE BIZNESU }\end{array}$ \\
\hline 1. & liczba jednostek sfery $\mathrm{B}+\mathrm{R}$ \\
\hline 2. & udział w krajowym zatrudnieniu w działalności B+R \\
\hline 3. & liczba pracowników naukowo-badawczych na 1000 osób aktywnych zawodowo \\
\hline 4. & krajowe nakłady na działalność badawczo-rozwojową w relacji do PKB \\
\hline 5. & $\begin{array}{l}\text { udział firm świadczących usługi dla biznesu z sektora fmansowo-ubezpieczeniowego } \\
\text { w ogólnej liczbie podmiotów gospodarczych }\end{array}$ \\
\hline 6. & $\begin{array}{l}\text { udział firm świadczących usługi dla biznesu - doradztwo, marketing, obsługa prawna } \\
\text { w ogólnej liczbie podmiotów gospodarczych }\end{array}$ \\
\hline 7. & udział pracujących w usługach dla biznesu w ogólnym zatrudnienıu \\
\hline 8. & $\begin{array}{l}\text { nakłady na działalność badawczo-rozwojową przez organizacje przemyslowe w relacji do } \\
\text { PKB (BERD) - pełna seria }\end{array}$ \\
\hline 9. & $\begin{array}{l}\text { odsetek pracujących w usługach o wysokim nasyceniu wiedzą i przemyśle wysokiej } \\
\text { technologii w zatrudnieniu ogółem }\end{array}$ \\
\hline 10. & zgłoszone wynalazki na 1 mln mieszkańców \\
\hline 11. & odsetek pracujących w sektorach produkcyjnych wysokiej techniki w zatrudnieniu ogółem \\
\hline 12. & odsetek pracujących w usługach wysokiej techniki w zatrudnieniu ogółem \\
\hline 13. & odsetek pracujących w usługach o wysokim nasyceniu wiedzą w zatrudnieniu ogółem \\
\hline & $\begin{array}{l}\text { INNOWACYJNA GOSPODARKA I OTOCZENIE BIZNESU } \\
\text { oziom lokalny (NUTS 4) }-3 \text { cechy charakteryzujące INNOWACYJNA GOSPODARKE, }\end{array}$ \\
\hline 1. & $\begin{array}{l}\text { udział firm świadczących usługi dla biznesu z sektora fmansowo-ubezpieczeniowego } \\
\text { w ogólnej liczbie podmiotów gospodarczych }\end{array}$ \\
\hline 2. & $\begin{array}{l}\text { udział firm świadczących usługi dla biznesu - doradztwo, marketing, obsługa prawna } \\
\text { w ogólnej liczbie podmiotów gospodarczych }\end{array}$ \\
\hline 3. & udział pracujących w ushugach dla biznesu w ogólnym zatrudnieniu \\
\hline
\end{tabular}

Źródło: opracowanie własne

${ }^{2}$ Wykorzystano wszystkie cechy $\mathrm{w}$ danym aspekcie dostępne $\mathrm{w}$ analizowanym okresie po redukcji statystycznej cech wysoko skorelowanych. 


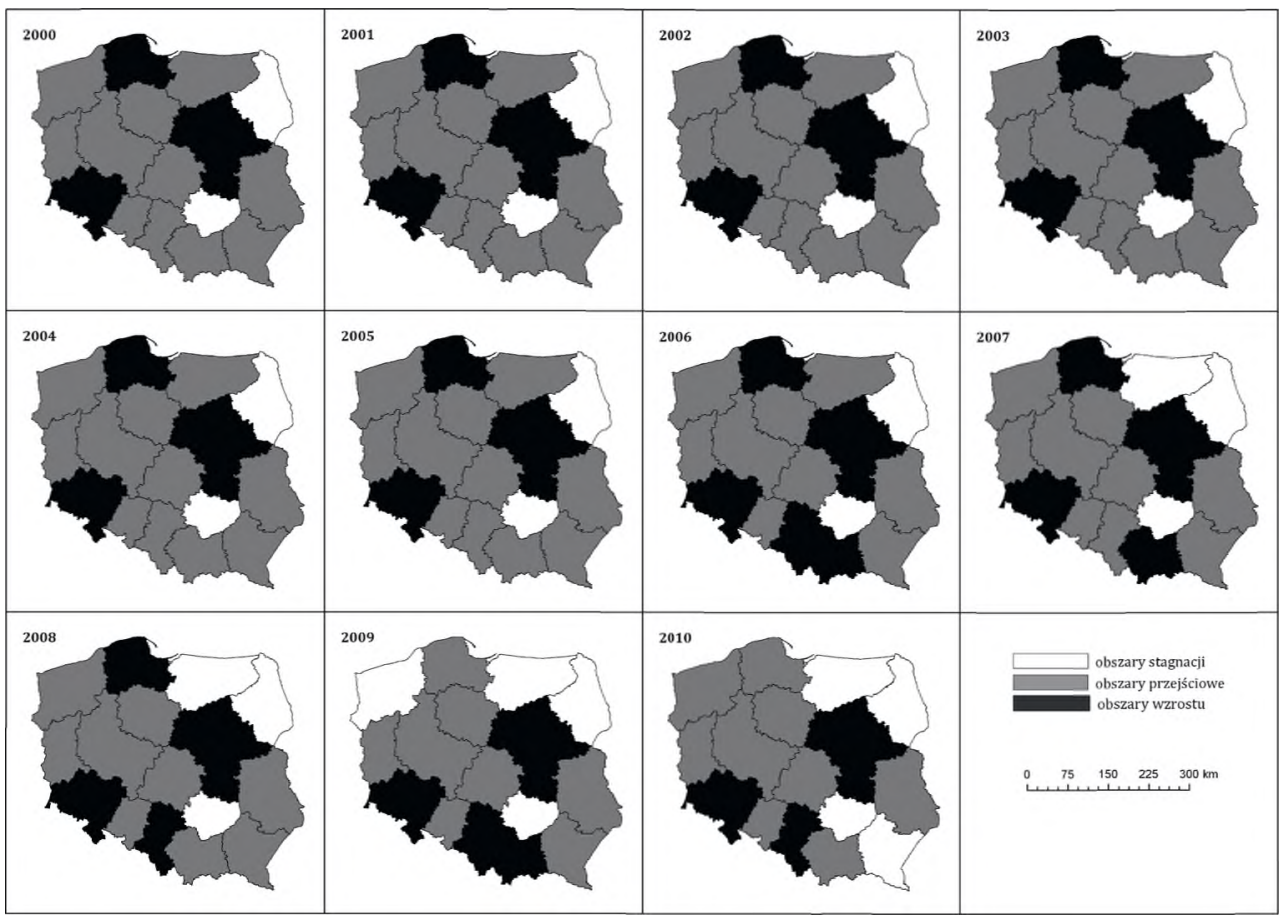

Ryc. 1. Rozkład obszarów wzrostu i stagnacji gospodarczej w aspekcie innowacyjnej gospodarki i otoczenia biznesu na poziomie regionalnym (NUTS2) w latach 2000-2010

Źródło: opracowanie własne

Od 2006 roku do grupy tej dolączylo również województwo śląskie. które (z wyjątkiem 2007 roku) pozostało tam do końca okresu analizy. Brak województwa pomorskiego wśród obszarów wzrostu gospodarczego w końcowym okresie analizy wy nikał z relatywnie niskiej dynamiki rozwoju w tym regionie. W drugim okresie analizy (2005-2010) rozwijało się ono słabiej niż województwa śląskie czy małopolskie, czego skutkiem byla utrata pozycji i spadek do grupy regionów przejściowych. Zmianę tę w największym stopniu determinowały: spadek wartości wskaźnika GERD (nakłady na B+R w stosunku do PKB) oraz spadek udziału zatrudnienia w uslugach wysokiej techniki. W tym samym okresie odnotowano wzrost dynamiki rozwoju województwa małopolskiego w aspekcie innowacyjności i otoczenia biznesu, przede wszystkim w zakresie liczby i zatrudnienia w jednostkach badawczo-rozwojowych oraz zatrudnienia w sektorach GOW, co skutkowało zaklasyfikowaniem tego regionu do obszarów wzrostu w latach 2006, 2007 i 2009. Do obszarów wzrostu periodycznie dolączało również województwo śląskie. Stanowiło to konsekwencję obserwowanej w tym województwie relatywnie wysokiej dynamiki wzrostu liczby jednostek $B+R$, wzrostu nakładów na dzialalność $B+R$ oraz wzrostu liczby zgłoszonych wynalazków na $1 \mathrm{mln}$ mieszkańców. Obszarami stagnacji w całym analizowanym okresie byly dwa województwa: podlaskie i świętokrzyskie. Charakteryzowały 
się one niskim udziałem firm świadczących uslugi dla biznesu i pracujących w sektorach wysokiej techniki, a także niewielką liczbą jednostek $B+R$ oraz niskim zatrudnieniem i nakładami finansowymi w sferze B+R. W 2007 roku do grupy obszarów stagnacji dołączyło także województwo warmińsko-mazurskie. które pozostalo w tej grupie do końca okresu analizy, czyli do 2010 roku. Jednorazowo w grupie regionów stagnacji znalazło się województwo zachodniopomorskie (w 2009 roku) oraz województwo podkarpackie (w 2010 roku). Przyczyną zaklasyfikowania województw warmińsko-mazurskiego oraz zachodniopomorskiego do klasy obszarów stagnacji byla przede wszystkim zidentyfikowana w tych regionach regresja rozwoju innowacyjności gospodarki i otoczenia biznesu (wskaźniki dynamiki wynosily poniżej 100\%). Szczególnie niskie wartości dotyczyły wskaźników efektów dzialalności innowacyjnej w zakresie zglaszanych wy nalazków oraz zatrudnienia w sektorach GOW. Województwo podkarpackie zostalo zaliczone do obszarów stagnacji w 2010 r. przede wszystkim w wyniku spadku zatrudnienia w sektorach wysokiej techniki.

Rozkład przestrzenny obszarów wzrostu i stagnacji gospodarczej na poziomie lokalnym (NUTS4) w aspekcie innowacyjnej gospodarki i otoczenia biznesu charakteryzowal się w badanym okresie, podobnie jak na poziomie regionalnym, relatywnie dużą stabilnością (ryc. 2). Należy jednak podkreślić, że cechy wykorzystane w analizie tego aspektu w układzie NUTS4, z powodu braku danych dotyczących innowacyjności, ograniczają się w zasadzie do analizy otoczenia biznesu w oparciu o uslugi dla biznesu. Ushugi te są dzialalnościami typowo miejskimi i ich występowanie jest silnie dodatnio skorelowane $\mathrm{z}$ liczbą ludności miast. W konsekwencji obszarami wzrostu w układzie NUTS4 w latach 2000-2010 są przede wszystkim miasta na prawach powiatu. Sytuacja ta nie uległa zmianie przez cały okres analizy. Największa liczba powiatów zaliczonych na podstawie analizowanych wskaźników do obszarów wzrostu występuje na terenie województwa śląskiego, które charakteryzowało się najwyższym wskaźnikiem urbanizacji w Polsce. Struktura danych determinowała również występowanie dodatkowej zależności - im większe miasto. tym wyższy odsetek zatrudnionych w usługach dla biznesu. stąd wysoka pozycja powiatów grodzkich i ziemskich wchodzących w skład największych aglomeracji miejskich. Obszary wzrostu stanowiły również miasta na prawach powiatu w takich województwach. jak: lubuskie, podkarpackie. podlaskie, lubelskie i świętokrzyskie, a także lódzkie. wielkopolskie i małopolskie, będące obszarami koncentracji ludności oraz dzialalności gospodarczej. W województwie dolnośląskim, poza miastami na prawach powiatów (Wroclawiem. Jelenią Góra i Legnicą). od 2002 roku do obszarów wzrostu zaliczany był powiat wałbrzyski, który wchłonął Wałbrzych - miasto wcześniej funkcjonujące jako miasto na prawach powiatu - co spowodowało znaczący wzrost udziału pracujących w usługach dla biznesu w powiecie. Poza powiatem wałbrzyskim w województwie dolnośląskim do obszarów wzrostu zaliczane były również powiaty głogowski oraz lubiński, na obszarze których funkcjonowały Legnicko-Glogowskie Zagłębie Miedziowe i Legnicka Specjalna Strefa Ekonomiczna - obszar koncentracji działalności przemysłowej, która była jednym z głównych czynników lokalizacji usług dla biznesu.

Podobne przypadki powiatów zaliczonych do obszarów wzrostu ze względu na wysoki poziom urbanizacji wystapily także w innych województwach (np. powiat 


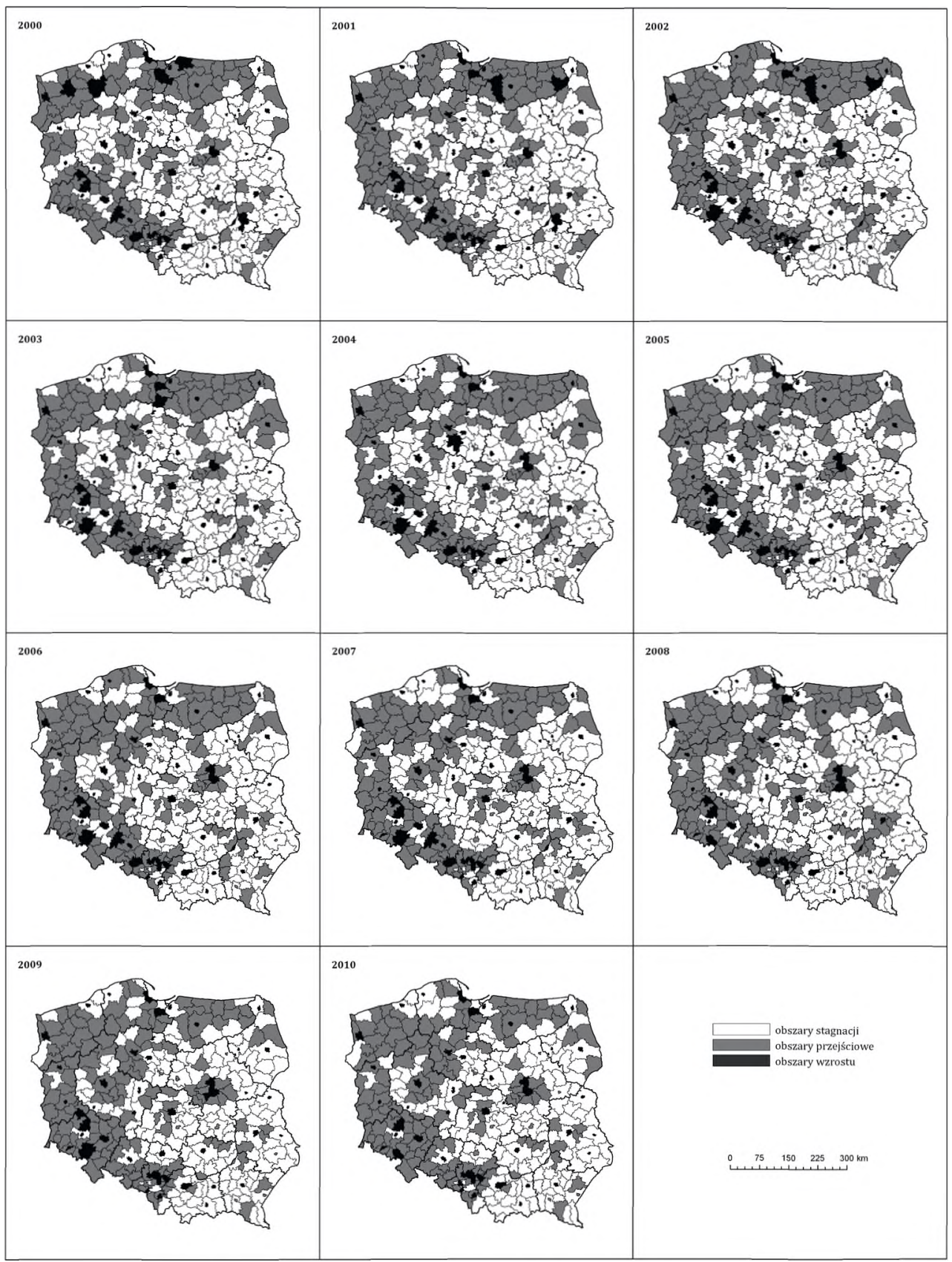

Ryc. 2. Rozklad obszarów wzrostu i stagnacji gospodarczej w aspekcıe ınnowacyjnej gospodarkı i otoczenia biznesu na poziomie lokalnym (NUTS4) w latach 2000-2010

Źródło: opracowanie własne 
kędzierzyńsko-kozielski - wskaźnik urbanizacji $67 \%$ oraz w niektórych latach powiat brzeski (w województwie opolskim). Dodatkowo oba powiaty znajdowały się na granicy obszarów wzrostu i obszarów przejściowych z powodu stosunkowo wysokiego udzialu podmiotów zarejestrowanych w sekcji obsługa nieruchomości i firm (K) przy jednocześnie niezbyt wysokim wskaźniku zatrudnienia w tej sekcji. Świadczy to o występowaniu w tych powiatach stosunkowo dużej liczby niewielkich firm świadczących usługi dla biznesu. Wśród obszarów wzrostu znalazły się także powiaty wchodzące w skład dużych aglomeracji miejskich. Przykladem powiat legionowski (który znalazl się wśród obszarów wzrostu niemal we wszystkich latach prowadzenia analizy) oraz piaseczeński i pruszkowski. Powiaty te polożone są w bezpośrednim sąsiedztwie Warszawy, stanowiąc obszar aglomeracji warszawskiej.

Obszary stagnacji na poziomie lokalnym (NUTS4) w aspekcie innowacyjnej gospodarki i otoczenia biznesu w znacznym stopniu koncentrowały się w pohudniowo-wschodniej oraz centralnej części Polski, przede wszystkim w województwach: podkarpackim, świętokrzyskim, podlaskim i małopolskim. w których notowano najniższy wskaźnik urbanizacji w Polsce, wynoszący około 45-49\%. Ich rozkład potwierdzały wskazane wcześniej zależności między poziomem rozwoju usług dla biznesu a poziomem urbanizacji. Nieliczne obszary przejściowe w tej części Polski były związane z powiatami grodzkimi (Krosno, Przemyśl) lub powiatami ziemskimi o relatywnie wysokich $w$ dany m województwie wskaźnikach urbanizacji (np. powiaty sanocki i stalowowolski w województwie podkarpackim: 47-60\%). Ze względu na specyfikę usług dla biznesu. będących usługami wielkomiejskimi, obszary przejściowe występowały głównie w otoczeniu obszarów wzrostu. tzn. w pobliżu dużych miast (miast wojewódzkich, powiatów grodzkich), m.in. wokół Warszawy. Poznania. Wroclawia. Torunia, Szczecina itp., a także w wysoko zurbanizowanym województwie śląskim i w pobliżu LGOM. Poza tym obszary przejściowe występowały także w województwach Polski północnej i zachodniej: warmińsko-mazurskim, lubuskim. zachodniopomorskim. Byly to zazwyczaj powiaty o przeciętnym w skali kraju (ale zdecydowanie wyższym w porównaniu z Polską południowo-wschodnią) wskaźniku urbanizacji. W latach 2000-2010 nie zaobserwowano znaczących zmian w układzie obszarów wzrostu i stagnacji gospodarczej w układzie NUTS4. Obserwuje się nieznaczne zwiększanie poziomu ushug dla biznesu w powiatach największych aglomeracji miejskich: Warszawy. Poznania. w mniejszym stopniu Łodzi, Wrocławia czy Krakowa. Wzrost znaczenia powiatów znajdujących się w bezpośrednim sąsiedztwie największych miast (czyli przejście z grupy regionów stagnacji do neutralnej), np. w przypadku powiatu poznańskiego, może być dowodem na postępującą mobilność usług dla biznesu. która jest od lat 90. XX w. obserwowana w obszarach metropolitalnych Stanów Zjednoczonych i Europy Zachodniej. Należy jednak podkreślić. że w przypadku aglomeracji polskich nie jest to jeszcze proces zaawansowany i nie dotyczy wszystkich aglomeracji miejskich. 
TRAJEKTORIE ROZWOJU OBSZARÓW WZROSTU I STAGNACJI GOSPODARCZEJ W ASPEKCIE INNOWACYNNEJ GOSPODARKI I OTOCZENIA BIZNESU

W aspekcie innowacyjnej gospodarki i otoczenia biznesu w układzie NUTS2 najliczniejszą klasę stanowi klasa obszarów przejściowych. Charakterystyka procesu rozwoju w tym aspekcie prowadzi do wniosku. że klasa ta dominowala w całym okresie analizy. jednak w latach 2000-2010 liczba województw wchodzących w skład tej klasy zmniejszyla się z 11 do 8 . W klasie obszarów wzrostu odnotowano w badanym okresie od 3 do 5 województw. a w klasie stagnacji od 2 do 5 województw. Spadkowi liczby województw w klasie obszarów przejściowych towarzyszył wzrost liczby województw wchodzących w skład obszarów stagnacji - z 2 (2000 r.) do 5 (2010 r.). Liczba województw w klasie wzrostu w pierwszych pięciu latach wynosila 3. następnie wzrosła do 5 (w 2006 i 2007 r.). a potem znów spadla do 3 (2010 r.).

Typologia regionów pod względem przebiegu procesu rozwoju w analizowanym okresie pozwala zidentyfikować pewne prawidłowości ich rozkładu. Obszary stałej sytuacji przejściowej koncentrują się w zachodniej i centralnej części kraju, natomiast województwa wchodzące w skład obszarów przejściowych przez 7-10 lat (klasa obszarów przejściowych) w Polsce południowo-wschodniej oraz pólnocnej. Obszary stałej stagnacji występują w Polsce wschodniej. Rozkład ten jest w dużej mierze skorelowany z poziomem rozwoju spoleczno-gospodarczego (ryc. 3).

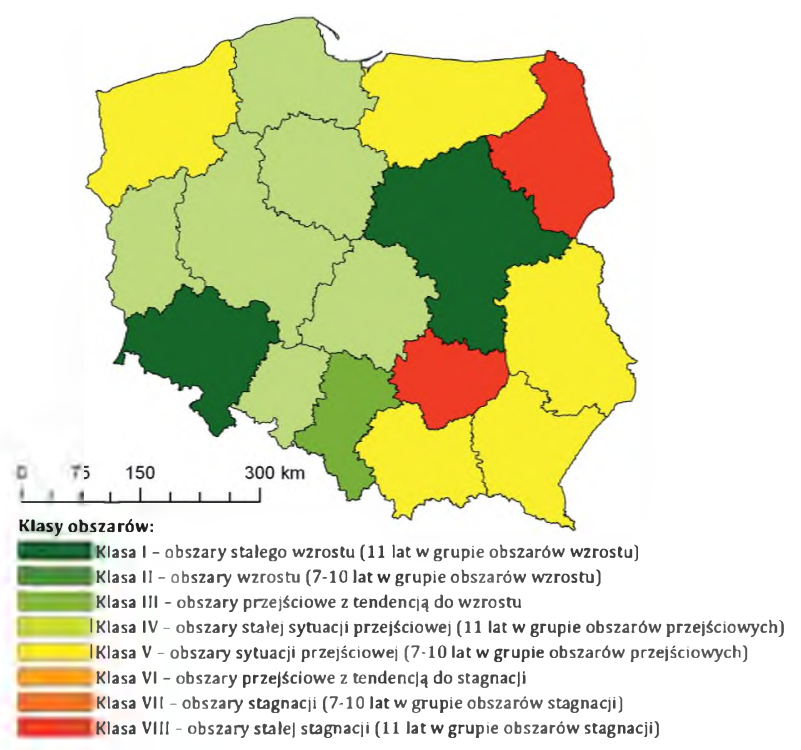

Ryc. 3. Rozklad przestrzenny klas obszarów wzrostu i stagnacji gospodarczej w aspekcie innowacyjnej gospodarki i otoczenia biznesu w układzie jednostek NUTS2

Źródło: opracowanie własne 


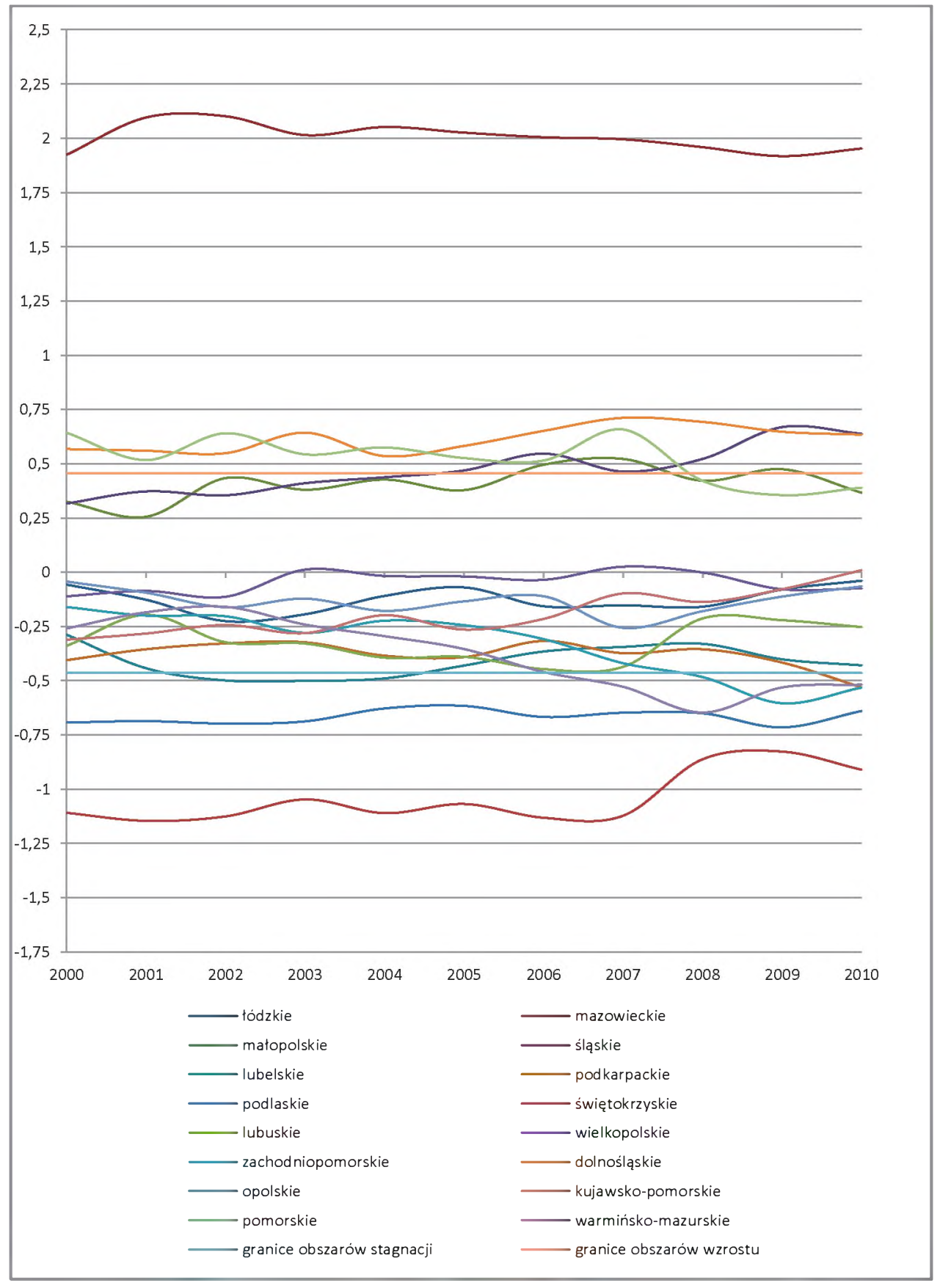

Ryc. 4. Trajektorie rozwoju województw w aspekcie innowacyjnej gospodarki i otoczenia biznesu w latach 2000-2010

Źródło: opracowanie własne 
Badanie dynamiki rozwoju obszarów wzrostu i obszarów stagnacji gospodarczej na poziomie regionalnym oparto na analizie dynamiki zmian wartości wskaźnika syntetycznego w aspekcie innowacyjnej gospodarki i otoczenia biznesu dla dwóch podokresów: 2000-2005 i 2006-2010. Jej wyniki pozwalają stwierdzić, że w pierwszym podokresie wszystkie województwa cechowały się dynamiką powyżej $100 \%$. natomiast w drugim podokresie ujemną dynamiką (poniżej 100\%) cechowały się województwa w północnej i zachodniej części kraju: zachodniopomorskie, lubuskie, warmińsko-mazurskie i kujawsko-pomorskie. Różnice pomiędzy poziomem dynamiki rozwoju w województwach w analizowanych podokresach były niewielkie i wynosiły od 101 do 103\%. W latach 2000-2005 najwyższą dynamikę poziomu rozwoju wykazały województwa: podkarpackie, mazowieckie, lubuskie, podlaskie, śląskie i wielkopolskie (wskaźnik dynamiki 103\%). W pozostałych województwach wskaźnik dynamiki wahał się w granicach 101-102\%. W drugim podokresie (2006-2010) wzrosła dysproporcja pomiędzy województwami w zakresie wartości wskaźnika dynamiki rozwoju. Najwyższą dynamiką rozwoju cechowalo się województwo śląskie (103\%). Z kolei wśród województw o ujemnej dynamice wzrostu znalazły się cztery, z których najniższą dynamikę ujawnilo województwo zachodniopomorskie (84\%) po 2008 roku. Nie odnotowano znaczących spadków dynamiki. które mogłyby być symptomami wpływu światowego kryzysu gospodarczego.

Rozkład wartości wskaźnika syntetycznego Perkala dla każdego z województw w latach 2000-2010 pozwala określić trajektorie rozwoju województw (ryc. 4). Rozstęp pomiędzy wartościami wskaźnika sumarycznego Perkala w analizowanym okresie nie ulegal znaczącym zmianom. Rozstęp tych wartości między 2000 a 2010 rokiem zmniejszyl się z 3,03 do 2.86. Najwyższą wartością wskaźnika syntetycznego (ok. 2) przez cały badany okres charakteryzowało się województwo mazowieckie. Najniższa wartość wskaźnika odnotowana w województwie świętokrzyskim zwiększyła się nieznacznie z-1.1 do 0.9. Województwa o największych nachyleniach krzywej to:

- śląskie. które w analizowanym okresie odnotowało wzrost wartości wskaźnika z 0.32 do 0.64 (co spowodowało także przesunięcie tego województwa z klasy obszarów przejściowych do klasy obszarów wzrostu od 2005 r.),

- kujawsko-pomorskie. gdzie odnotowano wzrost wartości analizowanego wskaźnika od -0.3 do 0 (zmiana ta nie spowodowała jednak zmiany klasy).

- świętokrzyskie. w którym wzrost wartości wskaźnika Perkala wynosił w badanym okresie 0,2 (zmiana ta nie spowodowała jednak zmiany klasy).

- pomorskie i warmińsko-mazurskie, w których odnotowano spadek wartości wskaźnika Perkala o 2,5, co spowodowało w przypadku województwa pomorskiego spadek z klasy obszarów wzrostu do obszarów przejściowych w 2008 roku. a w przypadku województwa warmińsko-mazurskiego spadek z klasy obszarów przejściowych do obszarów spadku.

Do jednostek cechujących się wartościami wskaźnika syntetycznego oscylującymi w granicach między obszarami wzrostu a pośrednimi należało województwo małopolskie. Wartości wskaźnika Perkala dla tego województwa kształtowały się na poziomie od 0.3 do 0,5 (przy granicy obszarów wzrostu wynoszącej 0.46). Spowodowało to zaliczenie województwa małopolskiego do klasy wzrostu w latach: 2006, 2007. 2009 i do klasy obszarów przejściowych w latach: 2000-2005 oraz 2008 i 2010. W odniesieniu do granicy pomiędzy 
obszarami przejściowymi a obszarami stagnacji przykładem jednostek ,,pogranicznych” jest województwo lubelskie. które w początkowym okresie analizy (2000-2001) zostalo zaklasyfikowane do obszarów przejściowych, następnie w latach 2003-2005 spadlo do klasy obszarów spadku, a od 2006 znów awansowało do klasy obszarów przejściowych.

Różnica między końcową a początkową wartością sumarycznego wskaźnika syntetycznego w 10 województwach uległa zmniejszeniu, wskazując na postępujące zjawisko konwergencji. Miało to miejsce w odniesieniu do następujących województw: warmińsko-mazurskiego, wielkopolskiego, lubuskiego, lódzkiego, mazowieckiego, świętokrzyskiego, opolskiego, pomorskiego, zachodniopomorskiego i śląskiego. Największy spadek rozpiętości analizowanego wskaźnika odnotowano w przypadku województwa warmińsko-mazurskiego $(-0,7)$ oraz wielkopolskiego $(-0,6)$. Został on spowodowany relatywnymi spadkami wartości wskaźników dla większości miast na prawach powiatów w województwie warmińsko-mazurskim i dla Konina w Wielkopolsce. Wzrost różnic między wartościami wskaźnika J. Perkala w latach 2000-2010 odnotowano w 6 województwach: lubelskim $(0,4)$, podkarpackim $(0,3)$, podlaskim, kujawsko-pomorskim $(0,1)$, dolnośląskim i malopolskim. W dwóch ostatnich różnica ta tylko nieznacznie odbiegala od 0. Dywergencja jest więc procesem charakterystycznym dla województw o slabszym poziomie rozwoju innowacyjnej gospodarki i otoczenia biznesu.

\section{CZYNNIKI WPLYWAJĄCE NA ROZMIESZCZENIE I ZMIENNOŚĆ OBSZARÓW WZROSTU} I OBSZARÓW STAGNACJI W ASPEKCIE: INNOWACYJNA GOSPODARKA I OTOCZENIE BIZNESU

Analizę czynników rozwoju aspektu innowacyjnej gospodarki i otoczenia biznesu prowadzono w układzie wszystkich powiatów (NUTS4) oraz osobno w ukladzie grup powiatów tworzących obszary wzrostu, obszary przejściowe i obszary stagnacji. W równaniach regresji wykorzystano z jednej strony cechy opisujące przedmiotowy aspekt. z drugiej - zestaw cech opisujących poziom rozwoju społeczno-gospodarczego w aspektach: ludność i osadnictwo. struktura gospodarki i rynek pracy. infrasruktura techniczna oraz sytuacja fiannsowa i poziom zamożności.

W układzie wszystkich badanych jednostek przestrzennych w wyniku analizy regresji przeprowadzonej dla 11 lat trwania obserwacji uzyskano zbiór 7 wskaźników, które przyporządkowano czterem czynnikom rozwoju (tab. 2).

Współczynnik determinacji dla otrzymanych równań regresji w większości przypadków oscylował na poziomie $0,80-0,85$. Oznacza to, że wyprowadzone modele, a za ich pomoca czynniki, w wy sokim stopniu wyjaśniają poziom rozwoju innowacyjnej gospodarki i otoczenia biznesu.

Spośród wyróżnionych czynników rozwoju przedmiotowego aspektu jako kluczowy przyjmuje się przede wszystkim odsetek ludności miejskiej (czynnik: poziom urbanizacji) i powiązaną z nim cechę: gęstość zaludnienia. Są to cechy oraz czynniki ściśle związane z miastami. Usługi dla biznesu analizowane w ramach przedmiotowego aspektu są usługami o lokalizacji typowo miejskiej, stąd poziom urbanizacji zostal zidentyfikowany jako najważniejszy 
Tab. 2. Czynniki rozwoju infrastruktury technicznej i dostępności przestrzennej w układzie wszystkich powiatów w Polsce

\begin{tabular}{|c|c|c|c|c|c|c|c|c|c|c|c|c|c|c|}
\hline 1.p. & Cecha & Czynnik & 2000 & 2001 & 2002 & 2003 & 2004 & 2005 & 2006 & 2007 & 2008 & 2009 & 2010 & Suma \\
\hline 1. & $\begin{array}{l}\text { Odsetek ludności } \\
\text { miejskiej }\end{array}$ & Poziom urbanizacji & $\mathrm{X}$ & $\mathrm{X}$ & $\mathrm{X}$ & $\mathrm{X}$ & $\mathrm{X}$ & $\mathrm{X}$ & $\mathrm{X}$ & $\mathrm{X}$ & $\mathrm{X}$ & $\mathrm{X}$ & $\mathrm{X}$ & 11 \\
\hline 2. & $\begin{array}{l}\text { \% ludności } \\
\text { korzystającej z sieci } \\
\text { gazowej }\end{array}$ & $\begin{array}{l}\text { Infrastruktura } \\
\text { komunalna }\end{array}$ & $\mathrm{X}$ & $\mathrm{X}$ & $\mathrm{X}$ & $\mathrm{X}$ & $\mathrm{X}$ & $\mathrm{X}$ & $\mathrm{X}$ & $\mathrm{X}$ & $\mathrm{X}$ & $X$ & $\mathrm{X}$ & 11 \\
\hline 3. & $\begin{array}{l}\text { \% ludności } \\
\text { korzystającej z sieci } \\
\text { wodociągowej }\end{array}$ & $\begin{array}{l}\text { Infrastruktura } \\
\text { komunalna }\end{array}$ & $\mathrm{X}$ & $\mathrm{X}$ & $\mathrm{X}$ & $\mathrm{X}$ & $\mathrm{X}$ & $\mathrm{X}$ & $\mathrm{X}$ & $\mathrm{X}$ & $\mathrm{X}$ & & $\mathrm{X}$ & 10 \\
\hline 4. & $\begin{array}{l}\text { Przeciętne miesięczne } \\
\text { wynagrodzenie brutto } \\
\text { w relacji do średniej } \\
\text { krajowej }\end{array}$ & Poziom zamożności & $\mathrm{X}$ & $\mathrm{X}$ & $\mathrm{X}$ & $\mathrm{X}$ & & $\mathrm{X}$ & $\mathrm{X}$ & $\mathrm{X}$ & $\mathrm{X}$ & $\mathrm{X}$ & $\mathrm{X}$ & 10 \\
\hline 5. & Gęstość zaludnienia & Poziom urbanizacji & & $\mathrm{X}$ & $\mathrm{X}$ & $\mathrm{X}$ & $\mathrm{X}$ & $\mathrm{X}$ & $\mathrm{X}$ & $\mathrm{X}$ & & $\mathrm{X}$ & $\mathrm{X}$ & 9 \\
\hline 6. & Gęstość sieci gazowej & $\begin{array}{l}\text { Infrastruktura } \\
\text { komunalna }\end{array}$ & $\mathrm{X}$ & $\mathrm{X}$ & $\mathrm{X}$ & & $\mathrm{X}$ & & $\mathrm{X}$ & $\mathrm{X}$ & $\mathrm{X}$ & $\mathrm{X}$ & $\mathrm{X}$ & 9 \\
\hline 7. & $\begin{array}{l}\text { Udział pracujących } \\
\text { w ushugach w ogólnej } \\
\text { liczbie pracujących } \\
\text { w gospodarce }(\%)\end{array}$ & Struktura gospodarki & & $\mathrm{X}$ & & & $\mathrm{X}$ & $\mathrm{X}$ & $\mathrm{X}$ & $X$ & $\mathrm{X}$ & $X$ & $X$ & 8 \\
\hline
\end{tabular}

Źródło: opracowanie własne 
czynnik ich rozwoju. Pozostałe wyróżnione cechy wiążą się raczej z poziomem urbanizacji. np. cechy: procent ludności korzystającej z sieci gazowej, procent ludności korzystającej z sieci wodociągowej, gęstość sieci gazowej w ramach czynnika: infrastruktura komunalna, czy cecha: udzial pracujących w usługach w ogólnej liczbie pracujących w gospodarce (\%) w ramach czynnika: struktura gospodarcza. Wśród najczęściej występujących cech warto także odnotować cechę: przeciętne miesięczne wynagrodzenie brutto w relacji do średniej krajowej (czynnik - poziom zamożności). Tutaj zależność wynika z faktu, że ushugi dla biznesu, zgodnie z teorią bazy ekonomicznej miasta. lokalizowane są najczęściej też w miejscach o największym potencjale przemyslowym. który również wpływa na zamożność mieszkańców.

Warto podkreślić. że wyróżnione czynniki w calym analizowanym okresie występowały z różną częstotliwością. W zbiorze czynników tylko 2 (przez 11 lat) wykazały istotną statystycznie zależność z poziomem rozwoju innowacyjnej gospodarki i otoczenia biznesu. Były to: poziom urbanizacji i infrastruktura komunalna. Poziom zamożności wystąpił 10 razy. a struktura gospodarki - dziewięciokrotnie.

Za najważniejszy czynnik rozwoju uważa się poziom urbanizacji. Miasta, w których koncentruje się działalność gospodarcza. stanowią glówny rynek zbytu na ushugi dla biznesu. Nie bez znaczenia stają się także coraz silniejsze powiązania sektora uslugowego z przemysłowym i wzajemne oddzialy wanie tych sektorów. To w miastach, przede wszystkich dużych, obserwuje się silną koncentrację usług wyższego rzędu (do których zalicza się uslugi dla biznesu). uwarunkowaną korzyściami aglomeracji, występowaniem wysokokwalifikowanych pracowników. uksztaltowanym środowiskiem naukowym i innowacyjnym. Dodatkowym aspektem jest rozwój eksternalizacji, prowadzący do koncentracji uslug dla biznesu w ograniczonej liczbie miejsc, zwykle w obszarach metropolitarnych.

Z kwestią poziomu urbanizacji wiążą się pozostale wyróżnione cechy: gęstość zaludnienia i infrastruktura komunalna. Większemu zagęszczeniu ludności towarzyszy większa gęstość infrastruktury technicznej, zwlaszcza komunalnej, niezbędnej do zapewnienia odpowiednich wanunków bytowych. To w miastach zazwyczaj lokalizowane są największe przedsiębiorstwa przemysłowe (czynnik: struktura gospodarki), które wplywają na poziom zamożności mieszkańców i sytuację finansową samorządów. Stanowią miejsca koncentracji działalności przemysłowej, które generują popyt na uslugi dla biznesu.

W przypadku czynników rozwoju innowacyjnej gospodarki i otoczenia biznesu w obszarach wzrostu, obszarach przejściowych i obszarach stagnacji sytuacja przedstawia się podobnie.

\section{Podsumowanie}

Przeprowadzona analiza aspektu: innowacyjna gospodarka i otoczenie biznesu prowadzi do następujących wniosków :

1. Województwa zaliczone do obszarów wzrostu (mazowieckie, dolnośląskie, okresowo: pomorskie, śląskie i małopolskie) to województwa o najwyższym poziomie rozwoju społeczno-gospodarczego. W ukladzie NUTS4 wyraźnie widoczna jest koncentracja obszarów 
o stałej przynależności do obszarów wzrostu - powiatów centralnej części województwa śląskiego oraz okolic aglomeracji warszawskiej i Trójmiasta. Obszary stagnacji koncentruja się w Polsce wschodniej.

2. Rozwój przedmiotowego aspektu w latach 2000-2010 nie następowal równomiernie. Odnotowano znaczące spowolnienie rozwoju po 2005 roku, jednak dotyczylo ono calego okresu 2006-2010. Nie odnotowano znaczą̧cych spadków dynamiki po 2008 roku. które mogłyby być symptomami wpływu światowego kryzysu gospodarczego

3. Do najważniejszych czynników rozwoju innowacyjnej gospodarki i otoczenia biznesu należy poziom urbanizacji. Wyniki niniejszej analizy potwierdzają znane w literaturze przedmiotu zależności dotyczące lokalizacji tego typu usług $w$ ośrodkach miejskich. co więcej - silnej korelacji wielkości miast z poziomem rozwoju tych usług. Duże miasta i aglomeracje miejskie o dużej koncentracji działalności gospodarczej (zarówno przemyslowej. jak i usługowej) stanowią największe rynki zbytu dla usług dla biznesu. To wlaśnie dzialalność gospodarcza lokalizowana w miastach generuje największy popyt na tego typu uslugi.

\section{Literatura \\ References}

Aydalot, P., Keeble, D. (1988). High technology industry and innovative environments: The European expierence. London: Routledge.

Chojnicki, Z. (1993). Postmodernistyczne zmiany globalnego porządku spoleczno-gospodarczego. Studia Regionalne i Lokalne, 12(45), 166-204.

Chojnicki, Z. (1999). Uwarunkowania rozwoju regionu nadgranicznego. Koncepcje i założenia teoretyczne. W: Z. Chojnicki (red.). Podstawy metodologiczne i teoretyczne geografii. Poznań: Bogucki Wydawnictwo Naukowe, 355-380.

Chmielewski, R., Stryjakiewicz, T., Twardowska, J., Waloszczyk, J. (2001). Innowacyjność przemyshu i jej zróżnicowanie w nowym układzie wojewódzkim. W: T. Czyż (red.). Zróżnicowanie społeczno-gospodarcze w nowym uktadzie terytorialnym. Biuletyn KPZK PAN, 197, 59-102.

Churski, P., Dominiak, J. (2012). Rola innowacji w kształtowaniu regionów rozwoju i stagnacji gospodarczej w Polsce. Studia Regionalne i Lokalne, 4(46), 54-77.

Doloreux D., (2002). What we should know about regional systems of innovation. Technology in society, 5(24), 3, 243-263.

Dominiak, J. (2004). Otoczenie biznesu jako czynnik rozwoju społeczno-gospodarczego. Przegląd Geograficzny, 76(2), 209-234.

Dominiak, J. (2006). Struktura i organizacja przestrzenna otoczenia biznesu w aglomeracji poznańskiej. Poznań: Bogucki Wydawnictwo Naukowe.

Dominiak J. (2013). Rola otoczenia biznesu w rozwoju regionalnym w Polsce. Prace Komisji Geografii Przemystu Polskiego Towarzystwa Geograficznego, 22, 44-64.

Hausner, J., Kudłacz, T., Szlachta, J. (1997). Instytucjonalne przesłanki regionalnego rozwoju Polski. Studia KPZK PAN, 106.

Kaluizhnova N., Osipov M. (2012). Instituional factors of innovation-oriented regional development. Prace Komisji Geografii Przemystu Polskiego Towarzystwa Geograficznego, 19, 116-125.

Lehner P., Todtling F., Trippl M. (2006). Innovation in knowledge intensive industries. The nature and geography of knowledge lınks. European Planning Studies, 14(8), 1035-1058.

Markiewicz J. (2007). Wpływ instytucji wsparcia na rozwój kooperacji i innowacyjność przedsiębiorstw w województwe zachodniopomorskim. Zeszyty Naukowe, 453, Ekonomiczne problemy ustug 8, Uniwersytet Szczecinski. 
Matusiak K.B. (2007). Systemy wsparcia przedsiębiorczości i procesów innowacyjnych. Zeszyty Naukowe, 453, Ekonomiczne problemy uslug 8, Uniwersytet Szczeciński.

Stryjakiewicz, T. (1999). Adaptacja przestrzenna przemyslu w Polsce w warunkach transformacji. Poznań: Wydawnictwo Naukowe UAM.

Tödtling F., Lehner P., Kaufmann A. (2008). Do different types of innovation rely on specific kinds of knowledge interactions. Wien: Institute of Regional Development and Environmnet. Retrieved from www.epub.wu.ac.at.

Wysocki J. (2009). Innowacje jako warunek rozwoju wsólczesnych przedsiębiorstw. Zeszyty Naukowe, 525, Ekonomiczne problemy uslug 28, Uniwersytet Szczeciński.

Joanna Dominiak, dr, adiunkt w zakładzie Analizy Regionalnej Instytutu Geografii Spoleczno-Ekonomicznej i Gospodarki Przestrzennej Uniwersytetu im. Adama Mickiewicza w Poznaniu. Zainteresowania naukowe koncentrują się wokół roli innowacyjności w ksztaltowaniu gospodarki opartej na wiedzy, wpływu otoczenia biznesu na rozwój regionów oraz przemian w strukturze ushug.

Joanna Dominiak, assistant professor in the establishment of the Regional Analysis Department in the Institute of Socio-Economic Geography and Spatial Management of Adam Mickiewicz University in Poznan. Scientific interests revolve around the role of innovation in the development of the knowledge based economy, the impact of the business environment on the development of regions, and changes in the structure of services.

\section{Adres/address:}

Uniwersytet im. A. Mickiewicza w Poznaniu Instytut Geografii Społeczno-Ekonomicznej i Gospodarkı Przestrzennej ul. Dzięgielowa 27, 61-680 Poznań, Polska e-mail: dominiak@amu.edu.pl 